\title{
CHARACTERISTICS OF SURFACE RECOMBINATION IN SILICON DIODE ISOLATION GROOVES *
}

\author{
E. Gaubas ${ }^{\text {a }}$, T. Čeponis ${ }^{\text {b }}$, D. Šalucha ${ }^{\text {b,c }}$, I. Šimkiené ${ }^{c}$, and A. Uleckas ${ }^{\text {a }}$ \\ ${ }^{a}$ Institute of Materials Science and Applied Research, Vilnius University, Saulettekio 10, LT-10223 Vilnius, Lithuania \\ E-mail: eugenijus.gaubas@ff.vu.lt \\ b Joint Stock Company "Vilniaus Ventos Puslaidininkiai", Ateities 10, LT-08303 Vilnius, Lithuania \\ ${ }^{c}$ Semiconductor Physics Institute, A. Goštauto 11, LT-01108 Vilnius, Lithuania
}

Received 9 July 2007; revised 14 September 2007; accepted 21 November 2007

\begin{abstract}
Carrier surface recombination characteristics are investigated in silicon high voltage diodes with glass isolated grooves by microwave probed photoconductivity transients (MW-PCT) combining different excitation depths within the layered device structures. Comparative analysis of recombination parameters in the device isolation grooves and layered wafers passivated by iodine-ethanol solutions is performed to evaluate surface recombination rates. It has been revealed that electrochemical etching-glass melting steps involved within the passivation technological procedures for fabrication of diode isolation grooves induce a decrease of surface recombination velocity from $3 \cdot 10^{3}$ to $10 \mathrm{~cm} / \mathrm{s}$.
\end{abstract}

Keywords: carrier lifetime, surface recombination, glass passivated isolation grooves, silicon high voltage devices

PACS: 61.72.Ji, 61.82.Fk, 72.40.+w

\section{Introduction}

Bevelled edge termination of the junctions by selectively etched moats is one of the basic technology types to enhance a breakdown voltage and switching rates [1] of the commercial power devices. Passivation of the junction surface within etched grooves is crucial in manipulation of device robustness to the high surface electric fields. The surface charge controlled by the passivants is also important in suppression of the leakage currents caused by surface recombination and in handling of the electric fields within bulk of devices. Therefore, different passivation techniques are being designed and exploited together with commonly used rubberized coatings, to increase stability of junction. Control of surface passivation characteristics is also important issue in improvement of junction isolation technologies.

In this work, passivation of moat surface by using electrochemical etching, formation of hydrogenrich porous silicon layers and glass in-melting steps has been investigated. Passivation quality has been controlled through measurements of surface recombination characteristics after each technological step by

\footnotetext{
${ }^{*}$ The report presented at the 37th Lithuanian National Physics Conference, 11-13 June 2007, Vilnius, Lithuania.
}

non-invasive technique employing microwave probed photoconductivity transients (MW-PCT). It has been shown that electrochemical etching-glass melting steps involved in passivation technological procedures result in a decrease of surface recombination velocity from $3 \cdot 10^{3}$ to $10 \mathrm{~cm} / \mathrm{s}$. Thus, the passivation allows one to reach the level of suppressed surface recombination velocity obtained for silicon wafers using the iodine ethanol solutions.

\section{Investigated structures}

Arrays of diode juntions, made of Si wafers with initial resistivity of $120 \Omega \mathrm{cm}$ and processed by phosphorus (for $n$-type) and boron (for $p$-type) diffusion, and separated by etched moats, have been investigated. Commonly, grooves of $100 \mu \mathrm{m}$ depth and $800 \mu \mathrm{m}$ width are etched using $\mathrm{HF}: \mathrm{HNO}_{3}: \mathrm{H}_{3} \mathrm{COOH}$ mixture. Then, the grooves are filled with $\mathrm{SiO}_{2}-\mathrm{PbO}-\mathrm{Al}_{2} \mathrm{O}_{3}-$ $\mathrm{B}_{2} \mathrm{O}_{3}$ glass and, as a final step, glass is in-melted at $750-760{ }^{\circ} \mathrm{C}$ temperature. Alternatively, as an additional pre-passivation stage, surface of the grooves has been etched in fluoric acid-ethanol (1:1) electrolyte for $20-180 \mathrm{~s}$ using current density of $20-30 \mathrm{~mA} / \mathrm{cm}^{2}$. 


\section{Measurement technique}

Carrier decay transients are measured by microwave (MW) probed photoconductivity (MW-PCT) technique based on microwave absorption by free carriers [2]. Excess carriers are generated by 500 ps laser pulses. Relaxation of excess carrier density is probed with $22 \mathrm{GHz}$ MW radiation. MW-PCT transient response is registered by Tektronix TDS-5104 oscilloscope. The transient components and relaxation rates are examined to identify the carrier recombination processes and to extract the particular parameters. To separate surface recombination parameters over diode and within groove, a sharply focused excitation beam has been utilised. Excitation wavelengths of 531 and $1062 \mathrm{~nm}$ are combined to vary excitation depth in layered structures under investigation.

\section{Theoretical basics for evaluation of parameters of surface recombination}

The effective lifetime $\tau_{\text {eff }}$ of the main decay mode is routinely considered to evaluate carrier decay rate. This effective lifetime can be approximated by expression

$$
\tau_{\text {eff }}=\frac{1}{\tau_{\mathrm{b}}^{-1}+\left(\tau_{\mathrm{s}}+\tau_{\mathrm{D}}\right)^{-1}},
$$

as the result of both a bulk $\left(\tau_{\mathrm{b}}\right)$ and a surface $\left(\tau_{\mathrm{S}}\right)$ component. The surface component results from $\tau_{\mathrm{D}}=$ $d_{\text {eff }}^{2} /\left(\pi^{2} D\right)$ related to carrier diffusion and from $\tau_{\mathrm{s}}=$ $d_{\text {eff }} / s$ related to surface recombination velocity $s$. Here, $d_{\text {eff }}$ is the effective sample thickness and $D$ is the carrier diffusion coefficient. Absolute values of $\tau_{\text {eff }}$ are rather good characteristics of the material and surface passivation efficiency within qualitative analysis of recombination rates. To separate recombination parameters more precisely, the combined measurements of the decay amplitudes and instantaneous lifetimes [2] are employed by varying the excitation depth. Excitation depth is changed through varied absorption coefficient $\alpha$ for different wavelengths. Profile of the excess carrier density, $n(x)$, which can be modulated through initial excitation domain $n_{0}(\alpha)$, is integrated by MW probe over effective thickness $d_{\text {eff. }}$. The integrally averaged excess carrier density, $\langle n(t)\rangle_{d}$, is taken into account via partial coefficients $\left\langle A_{m}\right\rangle_{d}$, independent of the time $t$ and of coordinate $x$. The latter concentration, normalized to that of the initial $\delta$-pulsed excitation moment, i. e. to a peak value of transient, is also independent of absolute value of generated excess concentration. Carrier density relaxation is asymptotically

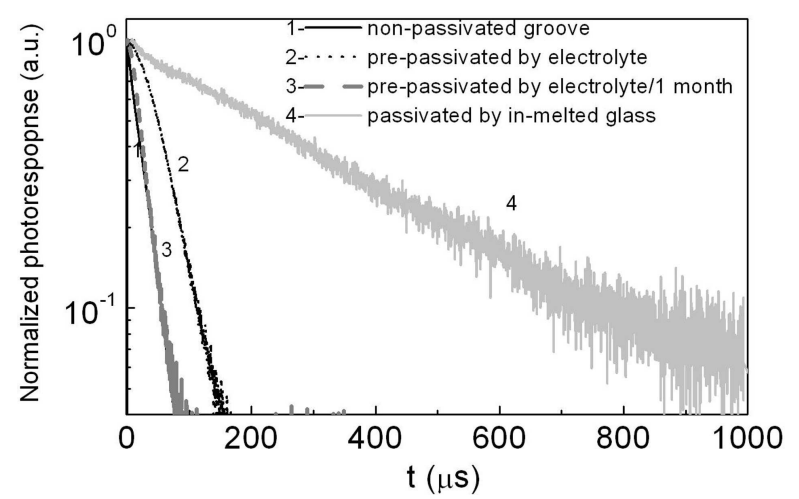

Fig. 1. Excess carrier density relaxation transients measured by MW-PCT technique within junction termination grooves for asetched moat surface (curve 1), for freshly pre-passivated by electrolyte (curve 2) as well as after long storage of the pre-passivated groove surface (curve 3), and for the passivated moat surface using in-melted glass (curve 4).

exponential due to very rapid stabilisation of profiles within small distances (i.e. for high space frequencies) during short times. This enables one to define the value of partial amplitude of the main decay mode by extrapolating the asymptotic decay slope to the initial moment $t=0$ within the normalized transients $\langle n(t)\rangle_{d, 0}$. This amplitude is then expressed by

$$
\left\langle A_{1}\right\rangle_{d}=\frac{8}{\left(\lambda_{1} d\right)^{2}\left[1+\left(\frac{D}{s d}\right)^{2}\left(\lambda_{1} d\right)^{2}+2 \frac{D}{s d}\right]},
$$

which allows direct evaluation of $s$ or $\lambda_{1} d$ value. Additionally, from the decay rate in asymptotic limit, the effective decay lifetime

$$
\tau_{\text {eff }}=\frac{1}{\tau_{\mathrm{b}}^{-1}+D \lambda_{1}^{2}}
$$

is directly measured, and its value is close to that described by Eq. (1). The parameters of the bulk and of the surface recombination can be simply separated by combining Eqs. (2) and (3).

\section{Variation of surface recombination characteristics with surface processing}

The microwave probed photoconductivity transients measured in the structures under investigation after various surface preparation procedures are illustrated in Fig. 1. Different carrier decay rates can be clearly deduced from the photoresponse transients normalized to the peak value attributed to various surface treatment procedures. The shortest effective lifetimes have been obtained for non-passivated moat surface, while the longest ones have been measured after in-melting of 


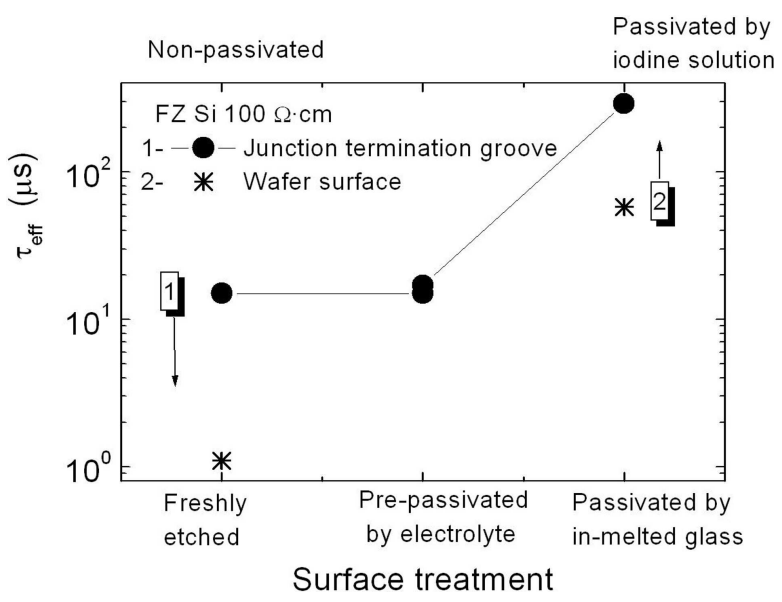

Fig. 2. Effective lifetime of the excess carrier decay under various surface treatments of the junction termination grooves compared with those measured in non-passivated and passivated wafer samples of the initial Si material. Circle symbols correspond to the bottom scale while stars to the upper one.

glass. A pre-passivation step by using an electrolysis procedure induces a slight increase of the effective lifetime, while this effect disappears after long storage.

Variation of the effective lifetime under the mentioned processings is shown in Fig. 2. The effective lifetime values measured within treated grooves (circle symbols) are compared with those obtained in wafer samples of nearly the same resistivity and technology for non-passivated surfaces and passivated by iodine solution, (star symbols) in Fig. 2. It can be deduced that the effective lifetime characterizes qualitatively the state of surface passivation rather well.

The effective thickness $d_{\text {eff }}=60 \mu \mathrm{m}$ has been defined for wafer samples rather precisely while it is difficult to estimate this parameter for isolation grooves. Therefore, values of surface recombination velocity can be estimated more reliably by comparing the effective lifetimes in wafers and grooves. From values of effective lifetimes, assuming parameters of carrier diffu-

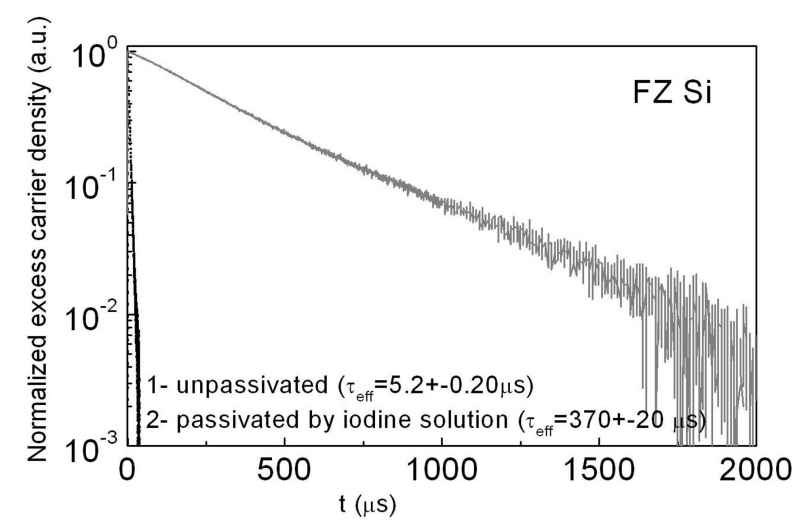

Fig. 3. Normalized excess carrier decays in pure FZ initial Si material with non-passivated and passivated wafer samples. sion and effective thickness for wafer samples, the parameter $s$ of velocity of the surface recombination has been estimated to be of 100 and $5.5 \cdot 10^{3} \mathrm{~cm} / \mathrm{s}$ for passivated and non-passivated surfaces, respectively. Then, values of $s$ have been evaluated to be of about $600 \mathrm{~cm} / \mathrm{s}$ for pre-passivated and much less than $100 \mathrm{~cm} / \mathrm{s}$ for groove surfaces passivated with in-melted glass, respectively. Long effective lifetimes of $300 \mu$ s measured in the grooves with in-melted glass indicate that carrier decay rate is governed by bulk recombination defects. Really, it has been determined that in the high resistivity Si wafers the long bulk lifetimes are inherent, Fig. 3, and passivation by iodine very significantly increases the effective lifetime to values of $\tau_{\mathrm{b}}>350 \mu \mathrm{s}$. Assuming values of bulk lifetime specific for FZ initial Si material and using Eq. (1), value of surface recombination has been estimated to be of $s \approx 10 \mathrm{~cm} / \mathrm{s}$ in termination grooves with in-melted glass.

To verify the estimated $s$ values in passivated grooves, the dual wavelength excitation regime has been employed in measurements of the MW-PCT transients. No significant decrease (curve 4, Fig. 1) has been detected within initial decay amplitude when an excitation domain is varied by changing excitation wavelength from 1062 to $531 \mathrm{~nm}$. Thus, small $s$ values have been corroborated by the decay amplitude method, Eq. (2). This indicates that $s$ values are really low for well passivated grooves.

\section{Conclusions}

Passivation quality of junction termination grooves has been investigated through variation of recombination characteristics measured by contactless MW-PCT technique. It is determined that surface recombination velocity $s$ decreases from values of $6 \cdot 10^{3} \mathrm{~cm} / \mathrm{s}$ to $s \leq$ $10 \mathrm{~cm} / \mathrm{s}$ under different surface treatments of junction termination grooves. The effective carrier lifetime in well passivated grooves approaches the values of the bulk recombination lifetime in the initial Si material.

\section{Acknowledgement}

This work was supported by the Lithuanian State Science and Studies Foundation.

\section{References}

[1] B.J. Baliga, Power Semiconductor Devices (PWS Publishing Company, Boston, 1996). 
[2] E. Gaubas, Transient absorption techniques for invesmaterials, Lithuanian J. Phys. 43, 145-165 (2003). tigation of recombination properties in semiconductor

\title{
PAVIRŠINĖS REKOMBINACIJOS BŪDINGIEJI DYDŽIAI PASYVUOTUOSE Si DIODŲ IZOLIAVIMO GRIOVELIUOSE
}

\author{
E. Gaubas ${ }^{\text {a }}$, T. Čeponis ${ }^{\text {b }}$, D. Šalucha ${ }^{\text {b,c }}$, I. Šimkiené ${ }^{\text {c }}$, A. Uleckas ${ }^{\text {a }}$

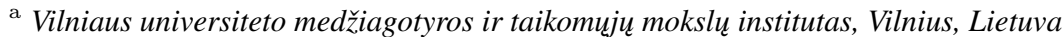 \\ ${ }^{\mathrm{b}}$ Akcine bendrové „Vilniaus Ventos puslaidininkiai“, Vilnius, Lietuva \\ ${ }^{\mathrm{c}}$ Puslaidininkiu fizikos institutas, Vilnius, Lietuva
}

\section{Santrauka}

Aptikta, kad pasyvuojant ir izoliuojant griovelio paviršių krūvininku efektinè gyvavimo trukmè kinta nuo 10 iki $300 \mu$ s. Tai atitinka paviršinès rekombinacijos greičio sumažèjimą nuo $6 \cdot 10^{3}$ iki $10 \mathrm{~cm} / \mathrm{s}$. Ivertinta elektrocheminio pasyvavimo senèjimo itaka stiklu izoliuoto griovelio paviršinès rekombinacijos charakteristikoms. 